\title{
IAMJ
}

INTERNATIONAL

AYURVEDIC

MEDICAL JOURNAL

\section{WILSON'S DISEASE WITH AYURVEDIC APPROACH - A CASE STUDY}

\author{
Renu Rani ${ }^{1}$, Satyawati Rathia ${ }^{2}$, V. K. Kori ${ }^{3}$, K. S. Patel ${ }^{4}$ \\ ${ }^{1} \mathrm{Ph} . \mathrm{D}$ Scholar, Kaumarbhritya Department, IPGT \& RA, Jamnagar, Gujarat, India \\ ${ }^{2}$ Assistant Professor, Kaumarbhritya Department, Shri NPA Govt. Ayu, College, Raipur, India \\ ${ }^{3}$ Assistant Professor, Kaumarbhritya Department, IPGT \& RA, Jamnagar, Gujarat, India \\ ${ }^{4}$ Professor and HOD, Kaumarbhritya Department, IPGT \& RA, Jamnagar, Gujarat, India
}

Corresponding Author: Renudhayal09@gmail.com

\section{https://doi.org/10.46607/iamj5708102020}

(Published online: October 2020)

Open Access

(C) International Ayurvedic Medical Journal, India 2020

Article Received: 18/09/2020 - Peer Reviewed: 29/09/2020 - Accepted for Publication: 03/10/2020

\section{(D) Check for updates}

\section{ABSTRACT}

Wilson disease is a rare, inherited autosomal recessive disease of copper metabolism. Loss of ATP7B function leads various grades of reduced biliary excretion of copper accumulation and toxicity of copper in the liver, brain and other tissues results in liver toxicity and other myriad manifestations of the disease. In classics there is no exact description of the disease entity which exactly matches the feature of Wilson disease, but it can be correlated with Sahaja Vyadhi or Janamjata Vyadhi. A 16-year-old female child diagnosed with Wilson disease complaints of improper gait, altered speech, chronic constipation and altered mental level etc. Investigation shows S. Ceruloplasmin- $0.4 \mathrm{mg} / \mathrm{dl}$, S. copper- within normal limit, slit lamp study for KF ring was positive. This patient was treated with Ayurvedic procedures i.e. Abhyanga, Swedana, Basti and Nasya along with oral medication. After two treatment protocol patient got symptomatic relief in clinical features. So, it can be concluded that quality of life (QOL) of patients with chronic disease can be improved with the help of internal Ayurvedic medication along with Panchkarma procedure.

Keywords: Ayurveda, Copper toxicity, Panchkarma, Wilson disease. 


\section{INTRODUCTION}

Wilson's disease (WD) is a rare, inherited autosomal recessive disorder caused by dysfunction of the copper transporter ATP7B, which is expressed mainly in hepatocytes and is critical for hepatic copper homeostasis and this defective gene causes impaired biliary copper excretion and accumulation in the liver, brain and other tissues. People who have Wilson's disease inherit two copies of an $A T P 7 B$ gene that are abnormal from the parent gene. It affects men and women equally. The starting age or the age when symptoms appears is around the 5 to 35 . But some studies showed that it can happen at the age of 2 to $72^{1}$. WD has a prevalence of approximately 1 in 30,000 live births ${ }^{2}$. The body receives copper from certain foods like mushrooms, turnip, greens spinach, eggplant, cashews, summer squash and most other with enriched vitamins. Too much high level of copper can cause life-threatening organ damages and poisoning in the body tissues. Common neurological symptoms of Wilson disease that may look like and progress with time comprise of tremor, involuntary movements, difficulty in swallowing (dysphagia), difficulty in speaking with poor articulation (dysarthria), spasticity, choreoathetoid and dystonic movements. Abnormally low ceruloplasmin level less than $5 \mathrm{mg} / \mathrm{dL}$ is discerned as the first step in the diagnosis of WD and 24-h copper values more than 100 $\mathrm{mg} / 24 \mathrm{~h}$ are usually appraised as diagnostic criteria of WD. Wilson disease diagnosed thorough clinical evaluation with complete patient history and some specified tests. These tests may consist of slit-lamp examination of the eyes for the presence of KayserFleischer rings; blood (serum) test which screens liver function and check the level protein that binds copper in blood (ceruloplasmin) and the level of copper in blood. Urine test that reveal abnormally high levels of copper excreted in the urine. In some patients, liver biopsy also performed for copper analysis to confirm diagnosis of Wilson disease ${ }^{3}$. Foods with high copper content like organ meats (liver), chocolates and nuts should be avoided. Treatment having two aspects: (i) induction therapy (ii) maintenance therapy. Induction therapy aims to reduce copper level to subtoxic thresh- old. This phase usually takes 4 to 6 months. D- penicillamine or trientine is often used as chelation therapy. Maintenance therapy aims to maintain a slightly negative copper balance so as to prevent its accumulation and toxicity. Zinc due to its lower cost and safety profile, can be used for this therapy ${ }^{4}$. Continuous lifelong pharmacotherapy is essential for management.

\section{Wilson disease and Ayurveda}

There is no description of the disease entity which exactly matches the feature of Wilson's disease in Ayurveda texts. It is an inherited Autosomal recessive disorder; thus, Acharya Charaka says about Beeja Dushti janya Vikara and Aadibala Pravrita Vyadhi (Susruta)

यस्य यस्य हयवयवस्य बीजे बीजभागे वा दोषा: प्रकोपमापध्द्यन्ते ।

तं तमवयवं विकृतिराविशति।। ( च. शा. ४/ ३०)

Vitiated Dosha may afflict the Beeja (ovam or sperm) and Beejabhaga (a part of Beeja nearest tem is chromosome/gene) by which the corresponding organs derived from these Beeja and Beejbhaga gets deformed. Its features resembling with the Vatavyadhi also. So, Wilson's disease may be correlated with Beejadoshjanya Vikara, Adibalapravruta Vyadhi, Sahajavyadhi and Vatavyadhi.

\section{Case Report}

A 16 years female child diagnosed case of Wilson's disease apparently normal with all her activities till her age of 13 years. Later she gradually develops with improper gait (hemiparetic), Involuntary jerky movements and spasticity of hands and legs, Improper speech (Dysarthria), Involuntary movements of hand and face- during speaking since 3 years, Indifferent mood, more of Irritability, Anger and restlessness, Loss of appetite, Fallen down during walking since 2 years, Chronic constipation- 1 times/8days since 2 years. As the day passes all her social response got more worsened and disease progress slowly. She took allopathic treatment for 3 years Tab. zinc $30 \mathrm{mg}$ twice daily but parents didn't observe any improvement. She was brought by her parents to KB OPD (on dated 18/03/2017) at PG Hospital, IPGT and RA, Jamnagar with above these complaints. She was born of full term 
normal vaginal delivery. She had a cried immediately after birth. Birth weight was $2.8 \mathrm{~kg}$. No H/O consanguineous marriage was found, and other siblings are normal.
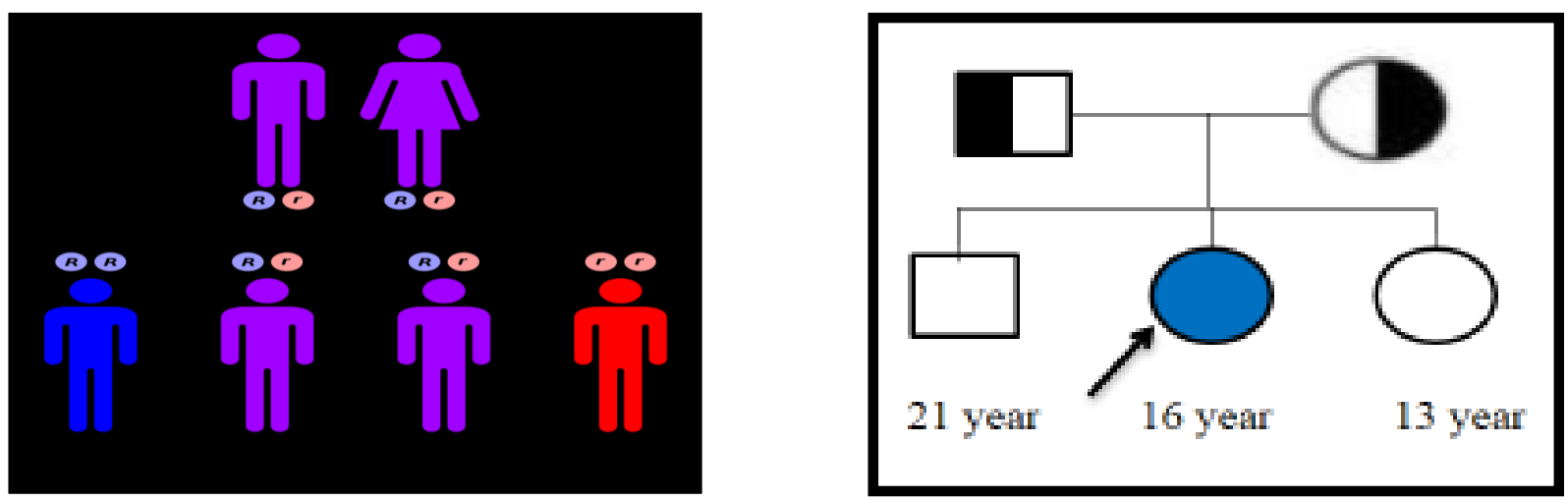

Figure 1: Pattern of Autosomal Inheritance

Immunization schedule was completed by her age. Her appetite was poor, Bowel was irregular, once in 8 days; urine was regular, 3-4 times per day, no bladder incontinence; with disturbed sleep, reduced to 3-5 hrs./day. Menarche age was 13year, Cycle was of 28 days and duration was 2 days, Frequency- normal and painful menstruation.

General Examination: Pulse rate-100/min, RR18/min, BP-118/78 $\mathrm{mm}$ of hg, conscious and well oriented, dysarthria in speech. Locomotor examination: Muscle Tone was increased $-\mathrm{R}>\mathrm{L}$, (both limbs) spasticity present, Involuntary movements present in neck \& Lt. Upper Limb, dystonia, striatal toes present, Deep tendon Reflexes were exaggerated, she had hemi paretic Gait. Systemic examinations: Vitals were normal. Nothing abnormal detected in Cardiovascular system, respiratory system and abdomen was soft without tenderness feeling.
Ashtavidha Pariksha: Nadi (pulse) was Vata Pita, Vata dominant. There was no complaint with regarding to Mutra (urine). Mala (stool) was Baddha (constipated); Jivhva (Tongue) was Sama Aavrita (coated); Shabda (speech) altered; Sparsha (touch) Samshitoshna; Drika (eyes) was Samanya (functioning normal); Aakrti (appearance) was Madhyama.

\section{Samprapti Ghataka}

Dosha- Vata Pitaja, Dusya- Rasa, Rakta, Mamsa, Meda, Agni- Mandagani, Srotasa- Rasavaha, Raktavaha, Mamsavaha, Medovaha, Udbhavasthana- Yakrita, Amapakvasaya, Shtrotodushtiprakara- Sanga, Vimarg Gamana, Vyaktisthana- Sarvsharira, AvyavaSarvanga, Sadhyasadhyata- Yapya

Investigations: CT scan of Brain shows ill-defined hypo dense area in bilateral thalami, basal ganglia and left parasagittal frontal lobe consistent with changes of Wilson's disease. 

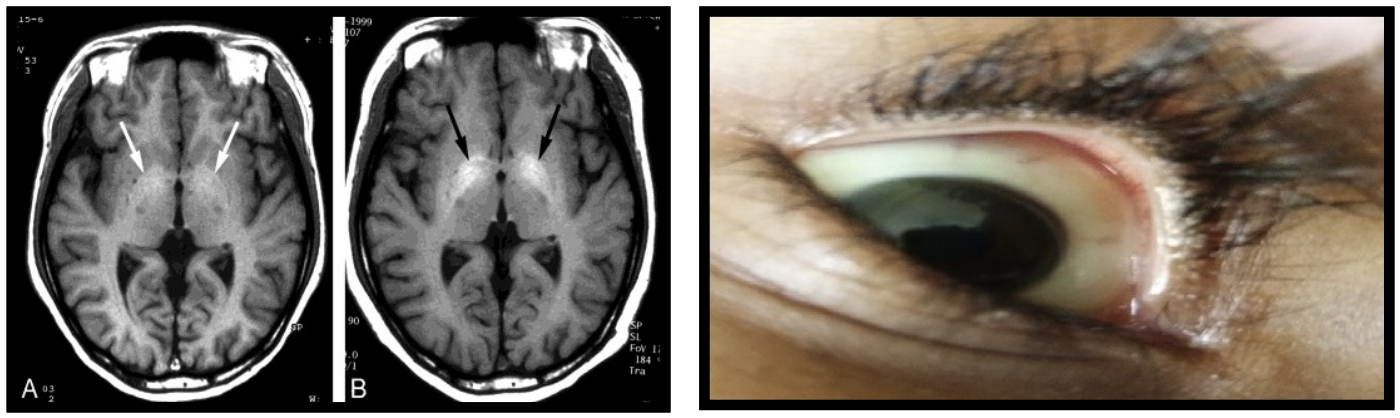

Figure 2: CT Scan of Brain and KF ring

USG of abdomen shows minimal coarse echo texture favors parenchymal disease. S. Ceruloplasmin was $4 \mathrm{mg} / \mathrm{dl}$ (low). S. Copper was within normal limit. S. globulin was low. Albuminurea present in urine. KF ring was Positive in Slit lamp study.

\section{Diagnostic Approach}

The patient was diagnosed case of Wilson disease. After a thorough clinical examination, the condition seemed to be Vatavyadhi according to Ayurveda. First, patient and her family (on dated 18/03/2017) had been counseled and explained about all the Ayurvedic procedures like Abhyanga, Swedana, Basti and Nasya and patient was admitted in IPD of Kaumarbhritya Department on dated 25/03/2017. After the parent's consent, procedures were done as per classics and schedule given below. Assessment was done after each course at the time of Admission and discharge. Patient was completed two procedure schedules.

- Date of $1^{\text {st }}$ admission and Discharge (32 days): 25/03/2017-26/04/2017

- Date of $2^{\text {nd }}$ admission and Discharge (32 days): 29/05/2017-29/06/2017

\section{Treatment Protocol}

\begin{tabular}{|c|c|c|c|}
\hline 1. & Deepana-Pachana & Aampachana Vati & 5 days \\
\hline 2. & Abhyanga with Nadi Sweda & Bala Taila & 5 days \\
\hline 3. & Matra Basti & Bala Taila & 8 days \\
\hline 4. & Nasya & Panchendriyavivardhna Taila & 14 days \\
\hline \multicolumn{4}{|c|}{ Oral medication: } \\
\hline 1. & $\begin{array}{l}\text { Medhya Churna (Brahmi, Shankhapushpi, } \\
\text { Guduchi, Yashtimadhu, Vacha and Pippalimula) }\end{array}$ & $4 \mathrm{gm}$ & $\begin{array}{l}\text { Twice a day Bhojanottara } \\
\text { with Sahapana of Madhu }\end{array}$ \\
\hline 2. & $\begin{array}{l}\text { Vidanga, Katuki, Yahsada Bhasma, Guduchi } \\
\text { Churna }\end{array}$ & $3 \mathrm{gm}$ & $\begin{array}{l}\text { Twice a day Bhojanottara with } \\
\text { Sahapana of Madhu }\end{array}$ \\
\hline 3. & Avipattikara Churna & $6 \mathrm{gm}$ & HS with lukewarm water. \\
\hline
\end{tabular}

The patient had advised to avoid mushrooms, turnip, greens spinach, eggplant, cashews, summer squash and most other with enriched vitamins, seafood (especially shellfish), organ meats (e.g., liver), whole grains, legumes (e.g., beans and lentils), cereals, potatoes, peas, mushrooms, chocolate, nuts (including peanuts and pecans), tea, grains such as wheat and rye and fruits (coconuts, papaya and apples) ${ }^{5}$. After 32 days of treatment, the patient was discharged.

\section{DISCUSSION}

A 16 years female child a known case of Wilson's disease apparently normal with all her activities till her age of 13 years. Later symptoms gradually developed, similar observations regarding the age of onset had been made in Eastern India ${ }^{6}$. In present case, improper gait (hemiparetic), involuntary jerky movements and spasticity of hands and legs, improper speech (Dysarthria), involuntary movements of hand and face were correlated to Sahaja Vyadhi or Vatavyadhi. As per Ayurveda due to its diverse manifestation, Wilson's 
disease can't be correlated directly with any disease. The root cause of the manifested disease was $A g$ nimandhya as patient having complaint of chronic constipation. Agnimandya at the Jatharagni level further led to Agnimandya at the Dhatvagni level. This led to the blockage of channels and ultimately caused Vata vitiation and metabolic disorders. Vatavyadhi (occurred due to Vata Dosha) in which there is a contraction, stiffness, pain in the joints, limbs rigidity, insomnia, tremors, etc. due to Nadi (nerves) and Sira (blood vessels) are afflicted by the aggravated $\mathrm{Vata}^{7}$. Ill-defined hypo dense area in bilateral thalami, basal ganglia and left parasagittal frontal lobe consistent with changes of Wilson's disease was found in CT scan. USG of abdomen shows minimal coarse echo texture favors parenchymal disease. Wilson's disease typically begins with a pre symptomatic period, during which copper accumulation in the liver cause's subclinical hepatitis and progresses to liver cirrhosis ${ }^{8}$. In this case $\mathrm{S}$. Copper was within normal limit but $\mathrm{S}$. Ceruloplasmin was $4 \mathrm{mg} / \mathrm{dl}$ (low) which suggest deposition of cu in different organs. In Urine test, Albuminuria persisted over longer periods, which suggests glomerular injury in some patients, possibly related to the use of D-penicillamine ${ }^{9}$. S. protein: low globulin, Low globulin levels can be a sign of liver or kidney disease $^{10}$. Slit lamp study for KF ring: Positive, KayserFleischer ring (KF rings) are dark rings that appear to encircle the iris of the eye. They are due to copper deposition in part of the cornea ${ }^{11}$.

Yashada Bhasma was added with the Combination of Vidanga, Katuki and Guduchi Churna. Zinc's contrivance of action involves the stimulation of intestinal cell metallothione in which obstructs copper absorption from the intestinal tract. It is typically used as maintenance therapy to prevent copper from building up again after treatment ${ }^{12}$ Guduchi plays a crucial role in the normalization of altered liver functions ${ }^{13}$ Acharya Charaka has mentioned four drugs under the heading of Medhya Rasayana viz. Guduchi, Shankhapushpi, Brahmi and Yashtimadhu. Vacha and Pippalimula are added in Medhya Churna. It was observed from many research studies that these drugs possess neuro-regenerative, neuro-protective and nootropic properties ${ }^{14}$. This formulation is having Vatahara, Medhya, Balya, Rasayana and Brimhana properties. The strong antioxidant and anti-inflammatory properties of Avipattikara Churna fights free radical damage and reduces inflammation that alleviates pain and swelling. That's why it is used for Mridu Virechana for removal of Pitta Dosha and constipation ${ }^{15}$. Initially to treat Agnimandya, Aampachana Vati was given for Deepana Pachana action. Contents of Aampachana Vati act to digest (waste food material) and prevent adhesion of the channels and patient got relief from constipation. $A b$ hyanga with Bala Taila and Nadi Swada was planned along with Matra Basti in Yoga Basti (Bala Taila) because for Vataja disorder Snehana (Oleation), Swedana (sudation) and Basti (Oil Enema) have been mentioned as the best treatment. Stabdhata (stiffness) was due to Sheeta (cold) Ruksha (dry) properties of Vata, Bala is having Snigdha (unctuous) and Bruhmana (nourishing) effect, Ushna Guna of Taila along with it helped in pacifying Vata Dosha thus helped in relieving Stabdhata (stiffness). Matra Basti (oil enema in minimum quantity) opted with the drug that were having Brimhana effect, so it nourished the body and pacified Vata Dosha. Due to lipid soluble content present in Panchendriyavivardhna Taila, it gets absorbed by the nasal olfactory cilia and stimulates the olfactory nerves which are connected with the higher centers of brain. Medhya and Vata-Kapha Shamaka properties of Panchendriyavivardhna Taila may give a synergistic action helping to correct the mental and intellectual functions.

\section{CONCLUSION}

Ayurvedic approach and diet modification have shown good results in reducing symptoms. Wilson disease is a rare, autosomal recessive inherited disorder of copper metabolism and comes under $\mathrm{Sa}$ haja Vyadhi or Vata Vyadhi in Ayurveda. Ayurvedic line of management gives satisfactory physically and mentally improvement. Patient got relief in many abnormal symptoms i.e. spasticity reduced, anger and irritable nature improved, appetite 
increased, constipation relieved, involuntary movements and walking pattern also improved. So, it can be concluded that by using Ayurvedic treatment protocol one can improve physical, social and mental health of a child. Rasayana drugs like Amalaki, Guduchi etc. which have the property of rejuvenation of cells or genes and Gandhakadi Yoga which eliminates copper from the body, by using these drug combinations with above treatment protocol gives much better results in future. Albeit with a single case study it can't be stated that this is the effective management for WD but the Ayurvedic approach of proper assessment of Dosha, Dushya and diet modifications may help in providing supportive care and improving the quality of life in such patients.

\section{Pictures of patients before and after treatment}

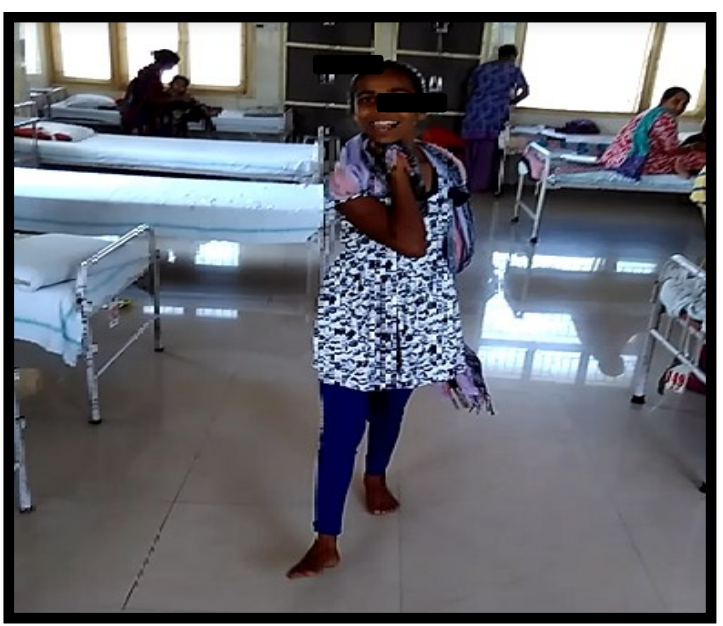

Improper gait and instability of body during walking (BT)

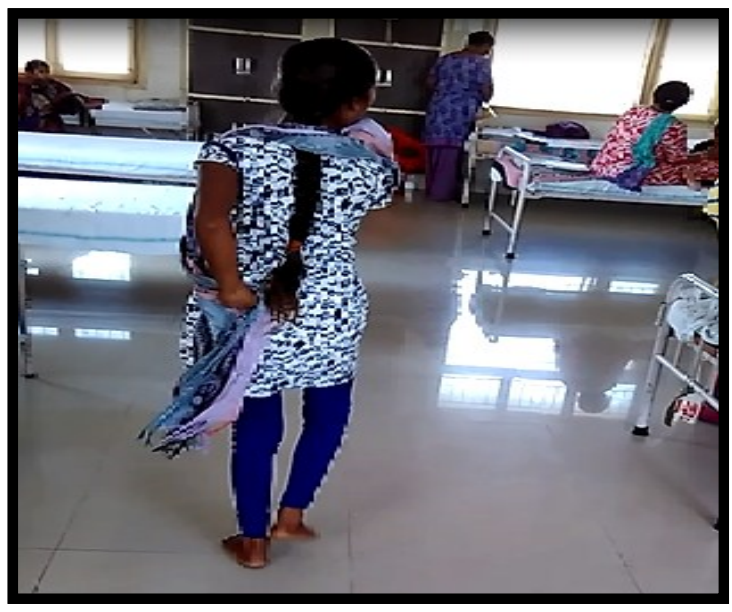

Instability of body during walking and using hands for proper balance (BT)

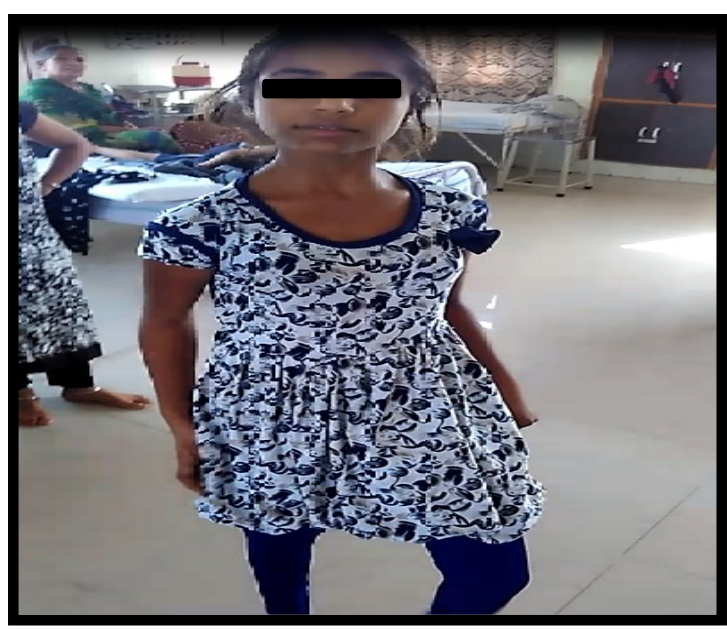

Improper gait but stability of body during walking (AT)

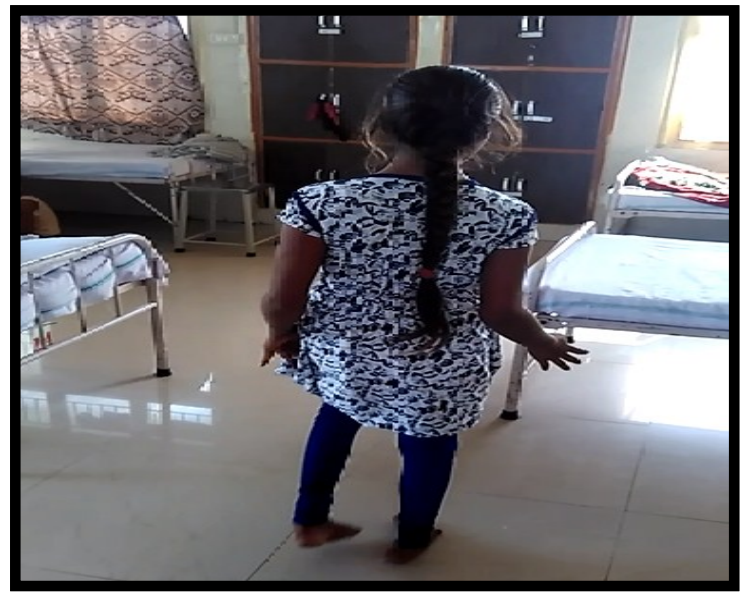

Backward posture showing a good balance (AT) 


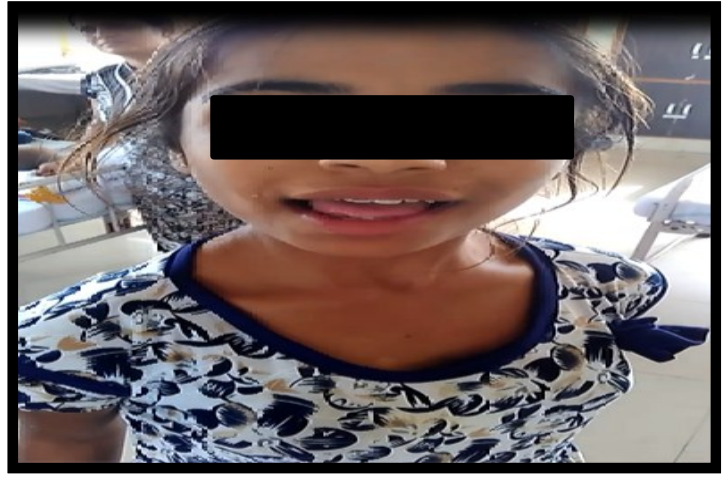

Facial features showing mental disturbance (BT)

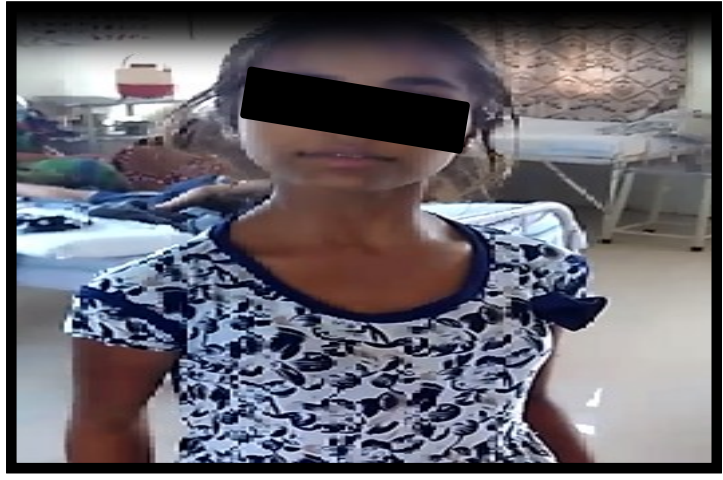

Facial features showing normal appearance (AT)

\section{REFERENCES}

1. https://www.mayoclinic.org/diseases-conditions /wilsons-disease/symptoms-causes/syc- 20353251

2. https://www.uptodate.com/contents/wilson-disease-epidemiology-and-pathogenesis retrieved on 28/7/18

3. https://www.mayoclinic.org/diseases-conditions/ wilsons-disease/diagnosis-treatment/drc- 20353256 retrieved on 31/7/18

4. Vinod K Paul, Arvind Bagga, editors Ghai essential pediatrics, disease of gastrointestinal system and liver, CBS Publishers and Distributors, New Delhi, Eigth edition, chapter 11, Pg 321

5. Kumar Tarun et al, Ayurvedic approach for management of Wilson's disease: A case report. Available from https://doi.org/10.1016/j.jaim.2019.09.004

6. Panagariya A, Sureka RK, Sharma AK, Dev A, Agarwal N. Wilson's disease: A study of 21 cases from northwest India. Ann Indian Acad Neurol 2007; 10:255-8

7. Shashtri K, Chaturvedi G, editors. Charaka Samhita of Agnivesha, Charaka, Dridhabala, Chikitsa Sthana; Gulma Chikitsa Adhyaya: Chapter 5, verse 94, Vatavyadhi Chikitsa Adhyaya: Ch.28,Verse 20-23, 45-48, Udara Chikitsa Adhyaya: Ch.13, Verse 38. 1st ed. Varanasi; Chaukhamba Bharti Acad-emy; 2007.p.214,780,784,785,387.

8. Clinical presentation, diagnosis and long-term outcome of Wilson's disease: a cohort study. https://pubmed.ncbi.nlm.nih.gov/16709660\#: :text=Coclsions \%3A\%20Patients\%20with\%20Wilson's\%20disease, than $\% 20$ patients $\% 20$ with $\% 20$ hepatic $\% 20$ symptoms.
9. Lower-than-normal ceruloplasmin levels may indicate the following: Wilson disease (a rare copper storage disease).Available from https://en.wikipedia.org/wiki/ Ceruloplasmin_-_cite_note-14

10. Proteinuria and Other Renal Functions in Wilson's Disease, https://pubmed.ncbi.nlm.nih.gov/9203178/

11. https://en.wikipedia.org/wiki/Kayser $\% \mathrm{E} 2 \% 80 \% 93$ Fleischer_ring

12. Brewer GJ, Yuzbasiyan-Gurkan V, Young AB. Treatment of Wilson's disease.SeminNeurol1987;7: 20920.

13. Karkal YR, Bairy LK. Safety of aqueous of Tinospora cordifolia (Tc) in healthy volunteers: a double blind randomised placebo controlled study. Iran J PharmacolTher 2007;6:59e61.

14. Ranade Anagha V. Shende.; Neuro - pharmacological review on four Medhya Dravyas described by Charaka; IAMJ, Volume 1; Issue 2; March - April 2013. p.1-4

15. https://www.netmeds.com/health-library/post/avipattikar-churna-5-ways-this-ayurvedic-wonder-promotesgut-health retrieved on 19/05/2020

\section{Source of Support: Nil \\ Conflict of Interest: None Declared}

How to cite this URL: Renu Rani et al: Wilson's Disease With Ayurvedic Approach - A Case Study. International Ayurvedic Medical Journal \{online\} 2020 \{cited October, 2020\} Available from: http://www.iamj.in/posts/images/upload/4910_4916.pdf 
